\title{
Knowledge, Attitude and Practice Regarding
} Infection Control Measures Among HealthCare Workers at King Khaled Eye Specialist Hospital (KKESH) in Riyadh, KSA

najod Alshathri ( $\sim$ Najodsha@gmail.com )

King Khaled Eye Specialist Hospital

Research

Keywords: Infection prevention and control, Healthcare Workers, Knowledge, Attitude, Practice

Posted Date: October 22nd, 2021

DOl: https://doi.org/10.21203/rs.3.rs-958840/v1

License: (9) This work is licensed under a Creative Commons Attribution 4.0 International License. Read Full License 


\section{Abstract}

Background: Infections acquired in healthcare facilities have become an increasingly challenging issue worldwide. The prevention of infectious diseases is a critical issue since healthcare workers develop acquired infections while providing services to patients. However, infection prevention and control are challenging, especially in healthcare facilities. Thus, this study aimed to determine the level of knowledge, attitudes, and practices among healthcare workers in King Khaled Eye Specialist Hospital (KKESH).

Methodology: A cross-sectional survey was conducted at KKESH, total of 285 healthcare workers, including physicians, nurses, optometrists, radiographers, and ophthalmic assistants were investigated. A close-ended, self-administered questionnaire was used to assess knowledge, attitudes, and practices toward infection control prevention measures. Data analysis was performed using SPSS version 20. Chisquared was computed to identify associations between factors within the knowledge, attitudes, and practices of infection prevention.

Results: The study showed that $81 \%$ of respondents had good knowledge, $82 \%$ had a positive attitude, and only $59 \%$ had safe infection prevention practices. Doctors were more knowledgeable than other staff, and nurses showed a high level of positive attitude and safe practices. There was a statistically significant correlation between age, occupation, education, and years of experience with infection prevention practices among healthcare providers $(P<0.05)$. The availability of infection prevention guidelines was associated with excellent knowledge, a positive attitude, and safe practices.

Conclusion: The findings of this study revealed that most healthcare workers had adequate knowledge and displayed a positive attitude, but practices toward infection control were not sufficient. Therefore, regular training, that contain educational programs, should be supported to maintain the highest level of practice.

\section{Background}

There have been various global reports concerning life-threatening hospital-acquired infections (HAls). Patients are usually susceptible to get infections due to their weakened immune system or increased exposure to infections while in hospital. Despite improvements in infection prevention strategies, several hospitals are still facing challenges with infection control [1].

HAls are those acquired during the process of care in a hospital. The world health organization (WHO) reports that in developed countries, 7 out of 100 hospitalized patients will get at least one HAl during their stay, whereas 10 out 100 hospitalized patients will become infected in developing countries. Usually, HAls occur due to the transfer of infection from one patient to another by healthcare providers who do not strictly follow the necessary infection control measures [2]. Hence, healthcare workers are the foremost important factor in infection prevention as they are the first line of contact with the patient. 
Infection prevention and control are defined as any policy or procedure that focuses on improving the activities of healthcare providers and patients, which aim to minimize and prevent the transmission of infections in healthcare facilities [3], [4].Several factors should be considered in achieving a high level of infection control measures, such as increasing knowledge regarding infection prevention, behavior, and attitude adjustment, providing personal protective equipment, conducting training workshops, and place reminders in the workplace. Moreover, it is essential to know the level of knowledge, attitudes, and practices among healthcare workers regarding infection prevention and control to establish or develop efficient infection control measures [5].

To the best of our knowledge, this study is one of the first to assess the knowledge, attitudes, and practices regarding infection control measures among healthcare workers at King Khaled Eye Specialist Hospital (KKESH). The outcome of this study could contribute to enhancing the activities used to reduce the infection rate.

\section{Study Objectives}

The study's primary purpose is:

- Evaluate the knowledge, attitudes, and practices regarding infection prevention and control among healthcare workers

- Identify the associated factors of infection prevention among healthcare workers at the King Khaled Eye Specialist Hospital.

\section{Materials And Methodologies}

\section{Study design, setting and population}

A descriptive cross-sectional survey was used to assess the knowledge, attitudes, and practices regarding infection prevention and control measures among healthcare workers at the King Khaled Eye Specialist Hospital (KKESH) in Riyadh, Saudi Arabia. This hospital is a tertiary care facility that specializes in providing ophthalmic healthcare services. The healthcare workers studied were Doctor, Nurse, Optometrist, Radiologist and Ophthalmic assistant.

\section{Sample size}

The sample size was determined using a single population proportion formula, with a $95 \%$ confidence interval and $10 \%$ acceptable error margin, the minimum sample size was calculated 200 healthcare workers. The final sample size was increased to 285 for more validity and to represent the population 


\section{Data collection and measurements}

A self-administered questionnaire was used to obtain appropriate analysis data, including data regarding socio-demographics, knowledge, attitudes, and practices toward infection control prevention measures. The questionnaire was prepared through the literature review and consultation with experts in the field of infection control. The survey content involved several necessary elements, including the CDC and WHO guidelines, on infection prevention and control.

The scoring system for knowledge, attitudes, and practices regarding infection control measures were according to the scales:

- Good knowledge and practice: earning a score of $75 \%$ and above

- Moderate knowledge and practice: earning a score of $50-75 \%$

- Poor knowledge and practice: earning a score below 50\%

- Positive attitude: study participants who responded $50 \%$ and above

- Negative attitude: study participants who responded below $50 \%$

\section{Data quality control}

The pilot study was conducted on $10 \%$ of the same population selected from each category to ensure the content and face validity of the instrument.

Validity of the tool items were tested statistically for construct validity using the Pearson correlation coefficient, the Correlation was significant.

Reliability of the tool items were tested statistically for internal consistency using Cronbach's alpha coefficient test, $0.74,0.73$ and 0.77 which considered acceptable.

\section{Data analysis}

Data were coded, entered into an Excel spreadsheet, then statistically analyzed using the Statistical Package for Social sciences (SPSS ver. 20). They were then reported as descriptive statistics such as a frequency table and graphically using bar and pie charts.

The variables were compared using Chi-squared test to determine the significance relationship. The Pvalue is the probability level which considered statistically significant if less than 0.05 .

\section{Ethical considerations}


This study was ethically reviewed and approved by the KKESH research committee (institutional review board number 20146-P), and adhered to the tenets of the Helsinki declaration. No personal information such as name or ID number appeared on the questionnaire. The participants provided written consent before completing the questionnaire.

\section{Results}

Out of 350 distributed questionnaires, 285 participated in the study. Thus, the response rate $81.42 \%$.

\section{Demographic information}

Of the 285 respondents, 199 (69.8\%) were female, while 86 (30.2\%) were male. Around $231(81.1 \%)$ of participants had training in infection control. Most workers 266 (93.3\%) were aware that there was a manual on infection prevention guidelines (Tables 1). 
Table 1

Demographic information

\begin{tabular}{|c|c|c|c|}
\hline \multicolumn{2}{|l|}{ Demographic information } & \multirow{2}{*}{$\begin{array}{l}\text { Frequency } \\
109\end{array}$} & \multirow{2}{*}{$\begin{array}{l}\text { Percent } \\
38.2\end{array}$} \\
\hline Age & $\begin{array}{l}(20-30) \\
\text { Years }\end{array}$ & & \\
\hline & $\begin{array}{l}(31-40) \\
\text { Years }\end{array}$ & 91 & 31.9 \\
\hline & $\begin{array}{l}(41-50) \\
\text { Years }\end{array}$ & 63 & 22.1 \\
\hline & $(>50)$ Years & 22 & 7.7 \\
\hline \multirow[t]{2}{*}{ Gender } & Male & 86 & 30.2 \\
\hline & Female & 199 & 69.8 \\
\hline \multirow[t]{5}{*}{ Occupation } & Doctor & 67 & 23.5 \\
\hline & Nurse & 160 & 56.1 \\
\hline & Optometrist & 28 & 9.8 \\
\hline & Radiologist & 15 & 5.3 \\
\hline & $\begin{array}{l}\text { Ophthalmic } \\
\text { assistant }\end{array}$ & 15 & 5.3 \\
\hline \multirow[t]{3}{*}{ Education } & Diploma & 38 & 13.3 \\
\hline & $\begin{array}{l}\text { Bachelor's } \\
\text { degree }\end{array}$ & 176 & 61.8 \\
\hline & Higher & 71 & 24.9 \\
\hline \multirow[t]{4}{*}{ Year of experience } & $\begin{array}{l}\text { Less than } 1 \\
\text { year }\end{array}$ & 14 & 4.9 \\
\hline & $\begin{array}{l}(1 \text { to } 5) \\
\text { years }\end{array}$ & 71 & 24.9 \\
\hline & $\begin{array}{l}(5 \text { to } 10) \\
\text { years }\end{array}$ & 106 & 37.2 \\
\hline & $\begin{array}{l}\text { More than } \\
10 \text { years }\end{array}$ & 94 & 33.0 \\
\hline \multirow[t]{2}{*}{ Did you receive training related to infection control? } & No & 54 & 18.9 \\
\hline & Yes & 231 & 81.1 \\
\hline \multirow{2}{*}{$\begin{array}{l}\text { There is a manual listing of infection prevention and control } \\
\text { guidelines for healthcare workers in the hospital? }\end{array}$} & No & 19 & 6.7 \\
\hline & Yes & 266 & 93.3 \\
\hline
\end{tabular}




\section{Knowledge of healthcare workers toward infection prevention}

Most respondents 262 (92\%) knew that hospital-acquired infection can be transmitted by medical equipment. Of all the respondents, 254 (89\%) replied that standard precautions apply to all patients. Most healthcare workers $271(95 \%)$ responded that most infections were transmitted by hand and 267 (94\%) knew there is a need to change gloves between patients. Most participants 235 (82\%) were aware that the choice of PPE depends on the type of exposure. Most workers $216(76 \%)$ recognized that all equipment needs to be decontaminated before sterilization. However, only $89(31 \%)$ were aware that disinfection does not remove bacterial spores (Table 2).

In general, knowledge about infection prevention was assessed using 14 questions, and of the 285 participants, $232(81.4 \%)$ had good knowledge, 47 (16.5\%) had moderate knowledge, while $6(2.1 \%)$ had poor knowledge (Figure 1). 
Table 2

Knowledge of healthcare workers toward infection prevention

\section{knowledge of infection prevention among healthcare workers}

$\begin{array}{lll}\text { Disagree } & \begin{array}{l}\text { Idon't } \\ \text { know }\end{array} & \text { I agree }\end{array}$

$n(\%) \quad n(\%) \quad n(\%)$

K1 Hospital-Acquired Infections ( $\mathrm{HAI}$ ) is an infection that the patient got from the community.

K2 Hospital-Acquired Infections (HAl) can be transmitted by medical equipment such as a needle or tonometer.

K3 Standard precautions apply to all patients regardless of their diagnosis.

K4 All patients should be considered potentially infectious.

$\mathrm{K} 5$ If there are limited beds available, patients with communicable diseases can be admitted in the same room with other non-communicable patients.

$\mathrm{K} 6 \mathrm{The}$ hand is the most common vehicle of infection transmission in the healthcare facility.

$197(69.1 \%) \quad 16(5.6 \%) \quad 72(25.3 \%)$

$12(4.2 \%)$

$11(3.9 \%)$

262(91.9\%)

$16(5.6 \%)$

$15(5.3 \%)$

$254(89.1 \%)$

$25(8.8 \%)$

$14(4.9 \%) \quad 246(86.3 \%)$

$242(84.9 \%)$

$16(5.6 \%)$

$27(9.5 \%)$

K7 There is no need to change gloves between patients as long as there is no visible contamination.

K8 If the hands are visibly dirty/soiled, alcohol-based hand rubs are sufficient.

K9 The type of PPE chosen depends on the type of exposure and procedures.

K10 PPE should be used only whenever there is contact with blood.

K11 There is Post-exposure prophylaxis is used for managing injuries from an HIV-infected patient.

K12 Sharps injuries should be managed without the need for reporting.

K13 Every equipment needs decontamination before sterilization.

K14 Disinfection means the removal of all pathogenic microorganisms from the inanimate surface but does include the elimination of bacterial spores.
$9(3.2 \%) \quad 5(1.8 \%) \quad 271(95.1 \%)$

$267(93.7 \%) \quad 6(2.1 \%) \quad 12(4.2 \%)$

$227(79.6 \%) \quad 12(4.2 \%) \quad 46(16.1 \%)$

$22(7.7 \%) \quad 28(9.8 \%) \quad 235(82.5 \%)$

$241(84.6 \%) \quad 13(4.6 \%) \quad 31(10.9 \%)$

$32(11.2 \%) \quad 87(30.5 \%) \quad 166(58.2 \%)$

$254(89.1 \%) \quad 18(6.3 \%) \quad 13(4.6 \%)$

$32(11.2 \%) \quad 37(13.0 \%) \quad 216(75.8 \%)$

$89(31.2 \%) \quad 57(20.0 \%) \quad 139(48.8 \%)$

\section{The attitude of healthcare workers toward infection prevention}


Overall, 256 (90\%) of healthcare workers agreed that hospital-acquired infection can pose serious outcomes, with most respondents 249 (87\%) feeling comfortable telling patients to follow cough hygiene procedures. Around 235 (82\%) of participants washed their hands after removing gloves. Most participants $189(66 \%)$ had a negative attitude toward feeling that their workload affects the ability to apply infection prevention guidelines (Table 3 ).

In general, out of the 285 participants, $236(82 \%)$ had a positive attitude, and $49(17.2 \%)$ had a negative attitude (Figure 2).

Table 3

The attitude of healthcare workers toward infection prevention

\begin{tabular}{|llll|}
\hline Attitude of infection prevention among healthcare workers & I disagree & \multicolumn{1}{l}{$\begin{array}{l}\text { I don't } \\
\text { know }\end{array}$} & I agree \\
\cline { 2 - 3 } & $n(\%)$ & $n(\%)$ & $n(\%)$ \\
\hline $\begin{array}{l}\text { A1 Do you believe that hospital-acquired infection can } \\
\text { pose serious outcome }\end{array}$ & $5(1.8 \%)$ & $24(8.4 \%)$ & $256(89.8 \%)$ \\
$\begin{array}{l}\text { A2 Do you receive enough education regarding infection } \\
\text { control in the hospital }\end{array}$ & $32(11.2 \%)$ & $9(3.2 \%)$ & $244(85.6 \%)$ \\
$\begin{array}{l}\text { A3 You do not have to wash your hands after removed } \\
\text { gloves }\end{array}$ & $235(82.5 \%)$ & $7(2.5 \%)$ & $43(15.1 \%)$ \\
$\begin{array}{l}\text { A4 Feeling comfortable to tell coughing patients to follow } \\
\text { cough hygiene procedures }\end{array}$ & $17(6.0 \%)$ & $19(6.7 \%)$ & $249(87.4 \%)$ \\
$\begin{array}{l}\text { A5 Do you believe that vaccination decreases hospital- } \\
\text { acquired infection }\end{array}$ & $56(19.6 \%)$ & $39(14.7 \%)$ & $190(66.7 \%)$ \\
$\begin{array}{l}\text { A6 The workload affects your ability to apply infection } \\
\text { prevention guidelines. }\end{array}$ & $76(26.7 \%)$ & $20(7.0 \%)$ & $189(66.3 \%)$ \\
\hline
\end{tabular}

\section{The practice of healthcare workers toward infection prevention}

Overall, 234 (82\%) respondents gave education to patients regarding hospital-acquired infection. Most healthcare workers 280 (98\%) applied hand hygiene between each patient. Only 69 (24\%) did not use a surgical mask to protect from TB infection, and $256(90 \%)$ wore a mask to prevent infection transmitted by droplets. Most participants 216 (76\%) were vaccinated for the influenza virus for this year. More than half 207 (73\%) of the respondents did not use a wet N95 mask. Furthermore, 194 (68\%) avoided recapping the needle before disposal after use, and 170 (60\%) disposed of the sharp container before it was full (Table 4). 
In general, out of the 285 participants, 170 (59.6\%) had good practice, 97 (34.0\%) had moderate practice, and $18(6.3 \%)$ had poor practice (Figure 3$)$.

Table 4

The practice of healthcare workers toward infection prevention

\begin{tabular}{|c|c|c|c|}
\hline \multirow[t]{2}{*}{$\begin{array}{l}\text { Practice of infection prevention among healthcare } \\
\text { workers }\end{array}$} & I disagree & $\begin{array}{l}\text { I don't } \\
\text { know }\end{array}$ & I agree \\
\hline & $n(\%)$ & $n(\%)$ & $n(\%)$ \\
\hline P1 Give care education to patients about HAl? & $16(5.6 \%)$ & $35(12.3 \%)$ & $234(82.1 \%)$ \\
\hline $\begin{array}{l}\text { P2 Hand hygiene should be applied between each patient } \\
\text { contacts }\end{array}$ & $2(0.7 \%)$ & $3(1.1 \%)$ & $280(98.2 \%)$ \\
\hline $\begin{array}{l}\text { P3 Use a towel or paper to turn off the water faucet after } \\
\text { hand washing? }\end{array}$ & $16(5.6 \%)$ & $10(3.5 \%)$ & $259(90.9 \%)$ \\
\hline $\begin{array}{l}\text { P4 Gloves should be changed between different } \\
\text { procedures on the same patient. }\end{array}$ & $65(22.8 \%)$ & $20(7.0 \%)$ & $200(70.2 \%)$ \\
\hline $\begin{array}{l}\text { P5 Use a surgical mask to protect yourself from } \\
\text { pulmonary TB infection }\end{array}$ & 69( & 25 & $191(6$ \\
\hline $\begin{array}{l}\text { P6 Wearing a mask to prevent infections transmitted by } \\
\text { droplets? }\end{array}$ & $13(4.6 \%)$ & $16(5.6 \%)$ & $256(89.8 \%)$ \\
\hline $\begin{array}{l}\text { P7 Screening of patients are being done to detect } \\
\text { colonization even if no evidence of infection }\end{array}$ & $38(13.3 \%)$ & 74( & $173(60.7 \%)$ \\
\hline P8 Are you vaccinated for the Influenza virus for this year? & $54(18.9 \%)$ & $15(5.3 \%)$ & $216(75.8 \%)$ \\
\hline P9 A wet N95 mask can still be used & $207(72.6 \%)$ & $48(16.8 \%)$ & $30(10.5 \%)$ \\
\hline P10 Have you ever had a needle stick injury? & $98(34.4 \%)$ & $17(6.0 \%)$ & $170(59.6 \%)$ \\
\hline $\begin{array}{l}\text { P11 Needles should be always recap before disposal after } \\
\text { use to prevent injuries }\end{array}$ & $194(86.1 \%)$ & $23(8.1 \%)$ & $68(23.9 \%)$ \\
\hline P12 Sharp container disposed when they are full & $170(59.6 \%)$ & $31(10.9 \%)$ & $84(29.5 \%)$ \\
\hline
\end{tabular}

\section{Factors associated with the practice of healthcare workers on infection prevention}

In the analysis, gender and training on infection control were not significantly associated with practice on infection prevention. However, age, occupation, education, working experience, and availability of guidelines were significantly associated with practice, with those aged above 50 likely to have a safe practice of infection control, and staff nurses had a significantly better rate of good practice (Figure 4). Those with a bachelor's degree were more likely to have good practice of infection prevention. Regarding 
working experience, those with ten years and above were more likely to practice infection prevention than others. Those healthcare workers who adhered to IP guidelines in their workplace were more likely to practice infection prevention activities (Table 5.1 to 5.5 ).

\section{Table 5.1}

\section{Factors associated with the practice of staff on infection prevention}

\begin{tabular}{|c|c|c|c|c|c|c|c|}
\hline \multirow{2}{*}{\multicolumn{3}{|c|}{$\begin{array}{l}\text { Age *.1.1 Practice of infection } \\
\text { prevention among healthcare } \\
\text { workers }\end{array}$}} & \multicolumn{3}{|c|}{$\begin{array}{l}\text { SUM.P.1.1 Practice of infection } \\
\text { prevention among healthcare workers }\end{array}$} & \multirow{3}{*}{$\begin{array}{l}\text { Total } \\
109\end{array}$} & \multirow[t]{3}{*}{ Validation } \\
\hline & & & \multirow{2}{*}{$\begin{array}{l}\text { Poor } \\
7\end{array}$} & \multirow{2}{*}{$\begin{array}{l}\text { Moderate } \\
50\end{array}$} & \multirow{2}{*}{$\begin{array}{l}\text { Good } \\
52\end{array}$} & & \\
\hline Age & $1(20-30)$ & Count & & & & & \\
\hline & & $\begin{array}{l}\% \text { within } \\
\text { Age }\end{array}$ & $6.4 \%$ & $45.9 \%$ & $47.7 \%$ & $100.0 \%$ & $\begin{array}{l}\text { Chi- } \\
\text { Square= }\end{array}$ \\
\hline & $\begin{array}{l}2(31-40) \\
\text { Years }\end{array}$ & Count & 7 & 31 & 53 & 91 & $17.936^{\mathrm{a}}$ \\
\hline & & $\begin{array}{l}\% \text { within } \\
\text { Age }\end{array}$ & $7.7 \%$ & $34.1 \%$ & $58.2 \%$ & $100.0 \%$ & \\
\hline & $3(41-50)$ & Count & 3 & 13 & 47 & 63 & $\mathrm{DF}=6$ \\
\hline & & $\begin{array}{l}\% \text { within } \\
\text { Age }\end{array}$ & $4.8 \%$ & $20.6 \%$ & $74.6 \%$ & $100.0 \%$ & \\
\hline & $4(>50)$ Years & Count & 1 & 3 & 18 & 22 & \\
\hline & & $\begin{array}{l}\% \text { within } \\
\text { Age }\end{array}$ & $4.5 \%$ & $13.6 \%$ & $81.8 \%$ & $100.0 \%$ & $P=0.006$ \\
\hline \multirow[t]{2}{*}{ Total } & & Count & 18 & 97 & 170 & 285 & \\
\hline & & $\begin{array}{l}\% \text { within } \\
\text { Age }\end{array}$ & $6.3 \%$ & $34.0 \%$ & $59.6 \%$ & $100.0 \%$ & \\
\hline
\end{tabular}

Significant relation between the two variables, $p$-value $=0.006$ 
Table 5.2

Factors associated with the practice of staff on infection prevention

\begin{tabular}{|c|c|c|c|c|c|c|c|}
\hline \multicolumn{3}{|c|}{$\begin{array}{l}\text { Education * } 1.1 \text { Practice of infection } \\
\text { prevention among healthcare workers }\end{array}$} & \multicolumn{3}{|c|}{$\begin{array}{l}\text { SUM.P.1. } 1 \text { Practice of } \\
\text { infection prevention among } \\
\text { healthcare workers }\end{array}$} & \multirow[t]{2}{*}{ Total } & \multirow[t]{2}{*}{ Validation } \\
\hline & & & Poor & Moderate & Good & & \\
\hline \multirow[t]{6}{*}{ Education } & \multirow[t]{2}{*}{1 Diploma } & Count & 5 & 16 & 17 & 38 & \\
\hline & & $\begin{array}{l}\text { \% within } \\
\text { Education }\end{array}$ & $13.2 \%$ & $42.1 \%$ & $44.7 \%$ & $100.0 \%$ & $\begin{array}{l}\text { Chi- } \\
\text { Square }=9.735^{\mathrm{a}}\end{array}$ \\
\hline & \multirow{2}{*}{$\begin{array}{l}2 \\
\text { Bachelor's } \\
\text { degree }\end{array}$} & Count & 8 & 52 & 116 & 176 & \\
\hline & & $\begin{array}{l}\text { \% within } \\
\text { Education }\end{array}$ & $4.5 \%$ & $29.5 \%$ & $65.9 \%$ & $100.0 \%$ & $\mathrm{DF}=4$ \\
\hline & \multirow[t]{2}{*}{3 Higher } & Count & 5 & 29 & 37 & 71 & \\
\hline & & $\begin{array}{l}\% \text { within } \\
\text { Education }\end{array}$ & $7.0 \%$ & $40.8 \%$ & $52.1 \%$ & $100.0 \%$ & $P=0.045$ \\
\hline \multirow[t]{2}{*}{ Total } & & Count & 18 & 97 & 170 & 285 & \\
\hline & & $\begin{array}{l}\% \text { within } \\
\text { Education }\end{array}$ & $6.3 \%$ & $34.0 \%$ & $59.6 \%$ & $100.0 \%$ & \\
\hline
\end{tabular}


Table 5.3

Factors associated with the practice of staff on infection prevention

\section{Year of experience *.1.1 Practice of infection prevention among healthcare workers}

SUM.P.1.1 Practice of infection Total Validation prevention among healthcare workers

\begin{tabular}{|c|c|c|c|c|c|c|c|}
\hline & & & & & & & \\
\hline & & & Poor & Moderate & Good & & \\
\hline \multirow{8}{*}{$\begin{array}{l}\text { Year of } \\
\text { experience }\end{array}$} & \multirow{2}{*}{$\begin{array}{l}1 \text { Less } \\
\text { than } 1 \\
\text { year }\end{array}$} & Count & 0 & 11 & 3 & 14 & \\
\hline & & $\begin{array}{l}\% \text { within } \\
\text { Year of } \\
\text { experience }\end{array}$ & $0.0 \%$ & $78.6 \%$ & $21.4 \%$ & $100.0 \%$ & $\begin{array}{l}\text { Chi- } \\
\text { Square=34.070 }\end{array}$ \\
\hline & \multirow{2}{*}{$\begin{array}{l}2(1 \text { to } \\
5) \\
\text { years }\end{array}$} & Count & 3 & 35 & 33 & 71 & \\
\hline & & $\begin{array}{l}\% \text { within } \\
\text { Year of } \\
\text { experience }\end{array}$ & $4.2 \%$ & $49.3 \%$ & $46.5 \%$ & $100.0 \%$ & \\
\hline & \multirow{2}{*}{$\begin{array}{l}3(5 \text { to } \\
10) \\
\text { years }\end{array}$} & Count & 11 & 33 & 62 & 106 & $D F=6$ \\
\hline & & $\begin{array}{l}\% \text { within } \\
\text { Year of } \\
\text { experience }\end{array}$ & $10.4 \%$ & $31.1 \%$ & $58.5 \%$ & $100.0 \%$ & \\
\hline & \multirow{2}{*}{$\begin{array}{l}4 \text { More } \\
\text { than } \\
10 \\
\text { years }\end{array}$} & Count & 4 & 18 & 72 & 94 & $P<0.0005$ \\
\hline & & $\begin{array}{l}\% \text { within } \\
\text { Year of } \\
\text { experience }\end{array}$ & $4.3 \%$ & $19.1 \%$ & $76.6 \%$ & $100.0 \%$ & \\
\hline \multirow[t]{2}{*}{ Total } & & Count & 18 & 97 & 170 & 285 & \\
\hline & & $\begin{array}{l}\% \text { within } \\
\text { Year of } \\
\text { experience }\end{array}$ & $6.3 \%$ & $34.0 \%$ & $59.6 \%$ & $100.0 \%$ & \\
\hline
\end{tabular}

Significant relation between the two variables, $p$-value $<0.0005$ 


\section{Table 5.4}

Factors associated with the practice of staff on infection prevention

\begin{tabular}{|c|c|c|c|c|c|c|c|}
\hline \multirow{2}{*}{\multicolumn{3}{|c|}{$\begin{array}{l}\text { Did you receive training related to } \\
\text { infection control? *.1.1 Practice of } \\
\text { infection prevention among healthcare } \\
\text { workers }\end{array}$}} & \multicolumn{3}{|c|}{$\begin{array}{l}\text { SUM.P.1. } 1 \text { Practice of } \\
\text { infection prevention among } \\
\text { healthcare workers }\end{array}$} & \multirow[t]{2}{*}{ Total } & \multirow[t]{2}{*}{ Validation } \\
\hline & & & Poor & Moderate & Good & & \\
\hline \multirow{4}{*}{$\begin{array}{l}\text { Did you } \\
\text { receive } \\
\text { training } \\
\text { related to } \\
\text { infection } \\
\text { control? }\end{array}$} & \multirow{2}{*}{$\begin{array}{l}0 \\
\text { No }\end{array}$} & Count & 2 & 24 & 28 & 54 & \\
\hline & & $\begin{array}{l}\% \text { within Did } \\
\text { you receive } \\
\text { training related } \\
\text { to infection } \\
\text { control? }\end{array}$ & $3.7 \%$ & $44.4 \%$ & $51.9 \%$ & $100.0 \%$ & $\begin{array}{l}\text { Chi- } \\
\text { Square }=3.520^{\mathrm{a}}\end{array}$ \\
\hline & \multirow{2}{*}{$\begin{array}{l}1 \\
\text { Yes }\end{array}$} & Count & 16 & 73 & 142 & 231 & \\
\hline & & $\begin{array}{l}\% \text { within Did } \\
\text { you receive } \\
\text { training related } \\
\text { to infection } \\
\text { control? }\end{array}$ & $6.9 \%$ & $31.6 \%$ & $61.5 \%$ & $100.0 \%$ & $\mathrm{DF}=2$ \\
\hline \multirow[t]{2}{*}{ Total } & & Count & 18 & 97 & 170 & 285 & \\
\hline & & $\begin{array}{l}\% \text { within Did } \\
\text { you receive } \\
\text { training related } \\
\text { to infection } \\
\text { control? }\end{array}$ & $6.3 \%$ & $34.0 \%$ & $59.6 \%$ & $100.0 \%$ & $P=0.172$ \\
\hline
\end{tabular}

No Significant relation between the two variables, $p$-value $=0.172$ 
Table 5.5

Factors associated with the practice of staff on infection prevention

\section{There is a manual listing of infection prevention and control guidelines for healthcare workers in the hospital? .1.1 Practice of infection prevention among healthcare workers}

Total

\begin{tabular}{|c|c|c|c|c|c|c|c|}
\hline \multirow{4}{*}{$\begin{array}{l}\text { There is a } \\
\text { manual } \\
\text { listing of } \\
\text { infection } \\
\text { prevention } \\
\text { and control } \\
\text { guidelines for } \\
\text { healthcare } \\
\text { workers in the } \\
\text { hospital? }\end{array}$} & \multirow{2}{*}{$\begin{array}{l}0 \\
\text { No }\end{array}$} & Count & 5 & 10 & 4 & 19 & \\
\hline & & $\begin{array}{l}\% \text { within There } \\
\text { is a manual } \\
\text { listing of } \\
\text { infection } \\
\text { prevention } \\
\text { and control } \\
\text { guidelines for } \\
\text { healthcare } \\
\text { workers in the } \\
\text { hospital? }\end{array}$ & $26.3 \%$ & $52.6 \%$ & $21.1 \%$ & $100.0 \%$ & $\begin{array}{l}\text { Chi- } \\
\text { Square }=20.045^{a}\end{array}$ \\
\hline & \multirow{2}{*}{$\begin{array}{l}1 \\
\text { Yes }\end{array}$} & Count & 13 & 87 & 166 & 266 & \\
\hline & & $\begin{array}{l}\% \text { within There } \\
\text { is a manual } \\
\text { listing of } \\
\text { infection } \\
\text { prevention } \\
\text { and control } \\
\text { guidelines for } \\
\text { healthcare } \\
\text { workers in the } \\
\text { hospital? }\end{array}$ & $4.9 \%$ & $32.7 \%$ & $62.4 \%$ & $100.0 \%$ & $D F=2$ \\
\hline \multirow[t]{2}{*}{ Total } & & Count & 18 & 97 & 170 & 285 & $P<0.0005$ \\
\hline & & $\begin{array}{l}\text { \% within There } \\
\text { is a manual } \\
\text { listing of } \\
\text { infection } \\
\text { prevention } \\
\text { and control } \\
\text { guidelines for } \\
\text { healthcare } \\
\text { workers in the } \\
\text { hospital? }\end{array}$ & $6.3 \%$ & $34.0 \%$ & $59.6 \%$ & $100.0 \%$ & \\
\hline
\end{tabular}

SUM.P.1.1 Practice of infection prevention among

healthcare workers
Total Validation

Poor Moderate Good

Significant relation between the two variables, $p$-value $<0.0005$

\section{Discussion}




\section{The Knowledge of infection prevention among healthcare workers}

This study assessed the general level regarding knowledge of infection prevention showing that $81.4 \%$ of healthcare staff had good knowledge, which was higher than a study conducted in Ethiopia which showed $50.55 \%$ ]7[. This difference may be due to a much larger sample size in the current study. However, this result was lower than a study by Tasfai et al. (2020) ]8[, which reported 91.9\%. This difference may be due to the previous research excluded staff working less than two months. However, in this regard observing the level of knowledge in infection prevention could help control infection.

When each of the exact factors of measures was analyzed, better results have been observed in some of the items. For instance, A relatively high proportion of around $95 \%$ of respondents knew that the hand was the most common vehicle to transmit infection in healthcare facilities, which was higher than the result from a study conducted in Nigeria, which reported $86.3 \%$ ]9[. This variation might be attributable to the difference in sample size and setting, as the present study was conducted in all departments. In contrast, the previous study was conducted in an intensive care unit. Based on the results from the focused group discussion, there was adequate awareness to prevent the chances of infection within hospital facilities.

Most healthcare workers in the present study lacked sufficient knowledge regarding disinfection, with only $31 \%$ aware that disinfection does not eliminate bacterial spores. This finding is supported by a previous study that assessed staff knowledge, attitudes, and practices regarding the sterilization of instruments in India, which reported that the staff had insufficient knowledge about sterilization; thus, recommended providing hands-on training via programs and workshops ]10[.

The study revealed no significant correlation between age, gender, duration of work, and training with knowledge of infection prevention among healthcare workers. These results are supported by previous studies ]4[]11[ and ]12[. There was a statistically significant correlation between profession and availability of guidelines. The doctors had a significantly better rate of excellent knowledge toward infection control, possibly because they had a higher level of education. Those healthcare workers who had infection prevention guidelines in the hospital were more likely to be knowledgeable than those who did not.

\section{The attitude of infection prevention among healthcare workers}

This study assessed the general level regarding the attitude of infection prevention among healthcare staff, showing that $82 \%$ had a positive attitude, which was higher than that reported $69.32 \%$ by a study conducted in Ethiopia ]7[. This difference may be due to a much larger sample size in the current study. However, this result was lower than a previous study in 2019 which showed 100\% ]11[, possibly because healthcare workers try to be model subjects in filling questionnaire items. However, Folgori et al., ]13[, 
explains that the associated burden of disease related to hospital-acquired infections can be effectively controlled if the practitioners are well trained to have a positive attitude toward managing infectious symptoms. Encouraging a positive attitude has also been identified as a common way to reduce the risk associated with healthcare ]14[.

About $89 \%$ of the respondents interviewed agreed that hospital-acquired infections can pose serious outcomes, similar to a study conducted in 2019 , which indicated $83.6 \%$. ]8[, this agreement may be due to the participants of both studies had a similar background. A publication by Geberemariyam et al., (2018) ]15[, reported that positive activity by health service practitioners towards the management of infectious diseases has increased as majorities are seeing the benefits of such activities.

Some participants agree that they do not have to wash their hand after removing gloves, which reflect a negative attitude toward infection prevention. However, a study assessed the site of skin contamination after removing personal protective equipment and reported that the skin of healthcare workers was frequently contaminated during gloves removal ]16[.

The present study revealed no significant association between gender, duration of work, and training with the attitude of infection prevention among healthcare workers. However, there was a statistically significant association between age, profession, and guidelines. Healthcare workers aged 41-50 had a more positive attitude than other age groups, with nurses having a high rate of a positive attitude toward infection control, possibly due to the sample size. Also, those healthcare workers who had infection prevention guidelines in the hospital were more likely to have a positive attitude than those who did not.

\section{The practice of infection prevention among healthcare workers}

The general level regarding infection prevention practices in this study showed that $59.6 \%$ had good practices, $34.0 \%$ moderate practices, and $6.3 \%$ had poor practices. These results were low compared to a previous study in Ethiopia which showed 70.8\% displayed good practices ]17[. This difference may be due to the sampling technique. In this regard, this should have improved poor practices targeted to prevent infectious diseases that have propagated prevalence to outbreaks of hospital-acquired infections within hospital settings.

Healthcare workers should practice good hand hygiene before and after treating patients, and in the current study, $98 \%$ of participants applied hand hygiene between each patient contact. This is satisfactory evidence that healthcare workers are actively engaged in managing infectious diseases within the hospital environment. A similar study by Wong et al., (2019) ]18[, further noted that teaching hospitals have shown that participants often possess good hand hygiene practices as one of the most efficient ways of managing infection.

The current study demonstrated that about 73\% did not use a wet N95 mask. Moreover, most participants had poor practices in wearing an N95 mask to prevent Tuberculosis infection, which may be due to the 
lack of clear guidelines on precaution with TB patients. It could also be that staff do not perceive the risks of this practice; therefore, healthcare systems and policy should emphasize improving healthcare quality concerning infection prevention.

The study revealed no significant association between gender, taking training on infection control via infection prevention practices. However, age, occupation, education, working experience, and availability of guidelines were found to be significantly associated with infection prevention practices. These results are supported by a previous study (Desta et al., 2018) ]19[.

Age is a significant factor of practices toward infection prevention, with healthcare workers over 50 years more likely to practice infection prevention activities properly, possibly because years of experience reflect improved practices.

In the present study, nurses had a higher rate of good practices than others toward infection control, possibly due to the fact that nurses spent most of their time with patients, more than other hospital staff. Thus, they will comply with infection control measures regularly. Healthcare workers with a diploma had the lowest level of infection prevention practices; the highest rate was staff with bachelor's degrees. This might be because they have acquired essential information and infection prevention courses.

Staff who worked more than 10 years in the hospital were positively associated with better infection prevention practices than those who had worked less than 10 years. This could be because as the years of service increased, the staff was repeatedly exposed and gained information during their work.

The study indicated that those healthcare workers who adhere to the guidelines were more likely to practice infection prevention measures than those who did not adhere to the guidelines. This is in line with other studies in Ethiopia ]19[ and may be due to that those who adhered to the measures of infection control guidelines are aware of the updated information, which improves their practice.

However, there was no difference in knowledge, attitudes, and practices among trained and untrained staff, indicating the need for improvement in the content and quality of training.

\section{Conclusion}

The study demonstrated that most healthcare workers' knowledge and attitude toward infection prevention and control measures in the KKESH was acceptable, but the level of practice of more than onethird of healthcare providers toward infection prevention was slightly low. The good level of knowledge and attitude can be explained by the fact that the hospital and many instituted had conducted several online lectures during the COVID-19 pandemic as part of hospital preparedness against outbreaks. However, the findings show that good knowledge and positive attitude alone do not influence practice with approval infection control guidelines.

Doctors had the highest level of good knowledge, and nurses showed a high level of positive attitude and safe practice. Healthcare workers aware of infection prevention guidelines manual were significantly 
associated with having better knowledge, a positive attitude, and safe practice.

While most healthcare providers have adequate knowledge and a favorable attitude toward infection prevention, more effort is required in practice; thus, there is a need to support and improve infection prevention practices. Adequate in-service workshops and healthcare worker training should be encouraged to maintain the highest practices.

\section{Recommendations}

- The study recommended emphasizing education in the hospital included short training and workshop on hand hygiene, PPE, sterilization, and N95 masks. These trainings should be regularly to increase infection prevention practices among healthcare workers.

- In the future research observation study should be conducted to determine actual practices compared with their knowledge.

\section{Limitations of the study}

- The study was conducted in one health facility, which could not be generalized at a national level.

- Data obtained from healthcare workers through self-administrated that not confirmed with their actual practices on the ground.

\section{Abbreviations}

HAls: Hospital-acquired infections.

WHO: World health organization

KKESH: King Khaled eye specialist hospital

HCW: Healthcare workers

TB: Tuberculosis

\section{Declarations}

\section{Ethics approval and consent to participate}

This study was ethically reviewed and approved by the KKESH research committee (institutional review board number 20146-P), and adhered to the tenets of the Helsinki declaration. No personal information such as name or ID number appeared on the questionnaire. The participants provided written consent before completing the questionnaire. 


\section{Consent for publication}

Not applicable

\section{Availability of data and materials}

All data generated or analysed during this study are included in this published article

\section{Competing interests}

There are no competing interests

\section{Funding}

The study has not received any type of grants to support

\section{Author contributions}

NA responsible for the study. The author read and approved the final version of the manuscript

\section{Acknowledgement}

I would like to thank Dr. Atef Shibl, Alfaisal University for his guidance during this research. I am also thankful to King Khaled Eye Specialist Hospital for providing me with this opportunity to achieve my master's degree and many thanks to all the participants that took part in the thesis and enabled this research to be possible.

\section{References}

1. Carmen R, Yom-Tov GB, Nieuwenhuyse IV, Foubert B, Ofran Y. The role of specialized hospital units in infection and mortality risk reduction among patients with hematological cancers. Plos One. 2019;14(3):1-17.

2. Bolyard EA, Tablan OC, Williams WW, Pearson ML, Shapiro CN, Deitchman SD. The Hospital Infection Control Practices Advisory Committee. Guideline for infection control in health care personnel. Am J Infect Control. 1998;26(3):289-327.

3. Damani NN. Manual of infection prevention and control. Toronto: Oxford; 2012. University Press. Third Edition, 1-360. 
4. Al-Hammar L, Quadri S, Al-Braheem N, Albisher N, Al-souroj H, Al-Drees S, Al-Hammar A, Ali S. Knowledge of Standard Precautions among Healthcare Professionals in Saudi Arabia: Need for filling the gaps. International Journal of Scientific Research. 2017;6(4):588-91.

5. Sh H, Wm E, Es M, Fe M. (2017). Knowledge, Attitude and Practice of Infection. Prevention Measures among Health Care Workers in Wolaitta. Sodo Otona Teaching and Referral Hospital. Journal of Nursing \& Care, 06(04), 1-7.

6. WHO. (2021). Attacks on health care in the context of COVID-19. from https://www.who.int/newsroom/feature-stories/detail/attacks-on-health-care-in-the-context-of-covid-19.

7. Jemal S, Zeleke M, Tezera S, Hailu S, Abdosh A, Biya M, Abduljelil,S. (2018). Health Care Workers' Knowledge, Attitude and Practice Towards Infection Prevention in Dubti Referral Hospital, Dubti, North East Ethiopia. International Journal of Infectious Diseases and Therapy, 3(4), 66-73.

8. Tesfai B, Kibreab F, Mariam YK, Asmelash S, Guelay Y. (2020) Knowledge. Attitude. and Practice of health professionals on infection prevention in northern red-sea hospital, Eritrea. Journal of Community Medicine \& Health Education, 10(5) 1-8.

9. Adegboye M, Zakari S, Ahmed B, Olufemi G. (2018) Knowledge, awareness and. practice of infection control. by health care workers in the intensive care units of a tertiary hospital in Nigeria. African Health Science, 18(1), 72-78.

10. Sukhlecha A, Vaya S, Parmar G, Chavda K. Knowledge, attitude, and practice regarding sterilization among health-care staff in a tertiary hospital of western India. International Journal of Medical Science Public Health. 2015;4(10):1377.

11. Mandona E, Daniel EO, Abiodun PO, Popoola IO, Ojo OV, Adams CO, Moronkeji S. Assessment of Knowledge, Attitude and Practice of Infection Prevention Among Health Care Providers in Chibombo District Zambia. World. 2019;4(4):87-95.

12. Gulilat $K$, Tiruneh G. Assessment of knowledge, attitude and practice of health careworkers on infection prevention in health institution Bahir Dar city administration. Science Journal of public health. 2014;2(5):384-93.

13. Folgori L, Bielicki J, Heath PT, Sharland M. Antimicrobial-resistant Gram-negative infections in neonates: burden of disease and challenges in treatment. Curr Opin Infect Dis. 2017;30(3):281-8.

14. Oyemolade TA, Balogun JA, Akinkunmi MA, Ogunyileka OC, Arogundade FM, Olusola AJ. (2020). The burden of neurosurgical diseases in a rural southwestern Nigeria setting. World neurosurgery, 140, 148-152.

15. Geberemariyam BS, Donka GM, Wordofa B. Assessment of knowledge and practices of healthcare workers towards infection prevention and associated factors in healthcare facilities of West Arsi District, Southeast Ethiopia: a facility-based cross-sectional study. Archives of Public Health. 2018;76(1):1-11.

16. Olalekan AW, Olusegun BJ, Olufunmilayo EA, Lanre AO. Awareness and attitude of healthcare workers in a teaching hospital in Southwestern Nigeria towards nosocomial infections. Journal of Public Health Epidemiology. 2012;4(10):285-9. 
17. Assefa J, Diress G, Adane S. Infection prevention knowledge, practice, and its associated factors among healthcare providers in primary healthcare unit of Wogdie District, Northeast Ethiopia, 2019: a cross-sectional study. Antimicrobial Resistance Infection Control. 2020;9(1):1-9.

18. Wong JSW, Lee JKF. (2019). The common missed handwashing instances and areas after 15 years of hand-hygiene education. Journal of environmental and public health, 2019, 1-7.

19. Desta M, Ayenew T, Sitotaw N, Tegegne N, Dires M, Getie M. Knowledge, practice and associated factors of infection prevention among healthcare workers in Debre Markos referral hospital, Northwest Ethiopia. health services Research. 2018;18(465):1-10.

\section{Figures}

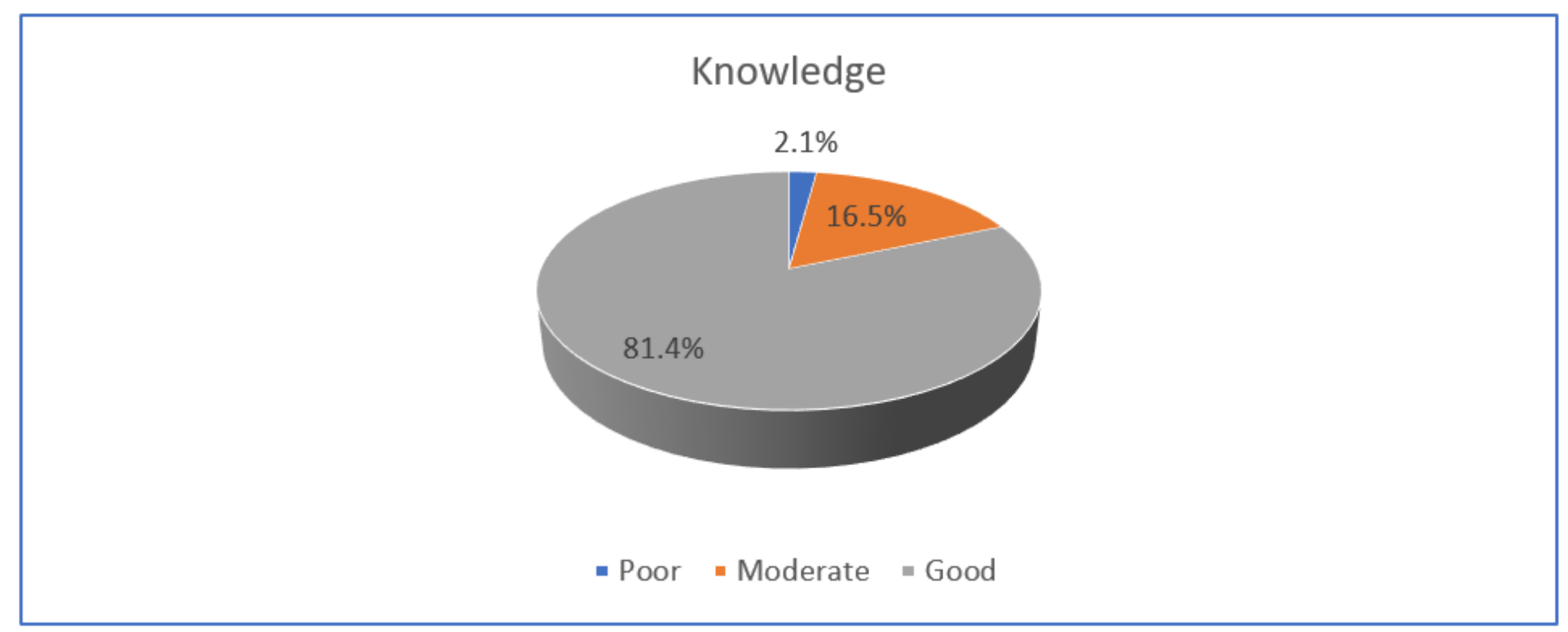

\section{Figure 1}

Distribution of knowledge regarding infection control among healthcare workers

\section{Attitude}

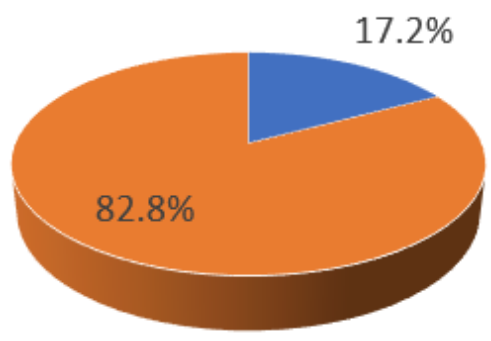

- Negative - Positive 
Figure 2

Distribution of attitude regarding infection control among healthcare workers

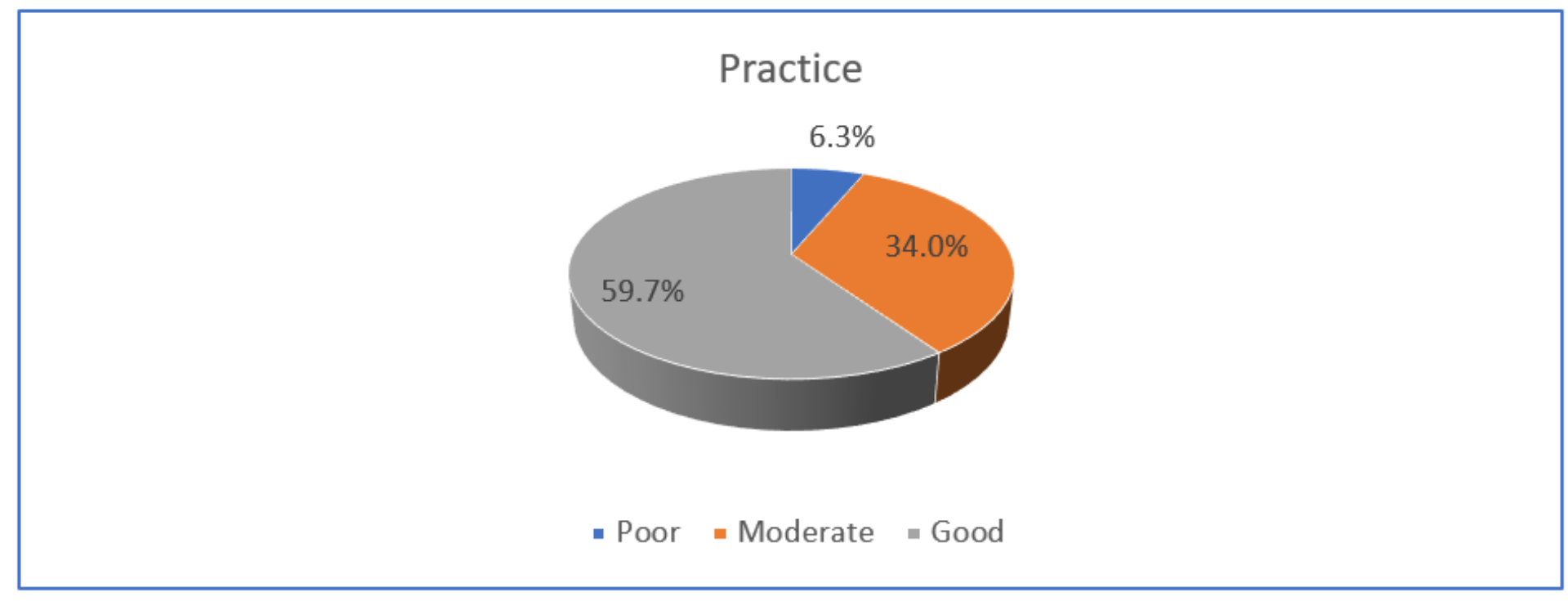

\section{Figure 3}

Distribution of practice regarding infection control among healthcare workers

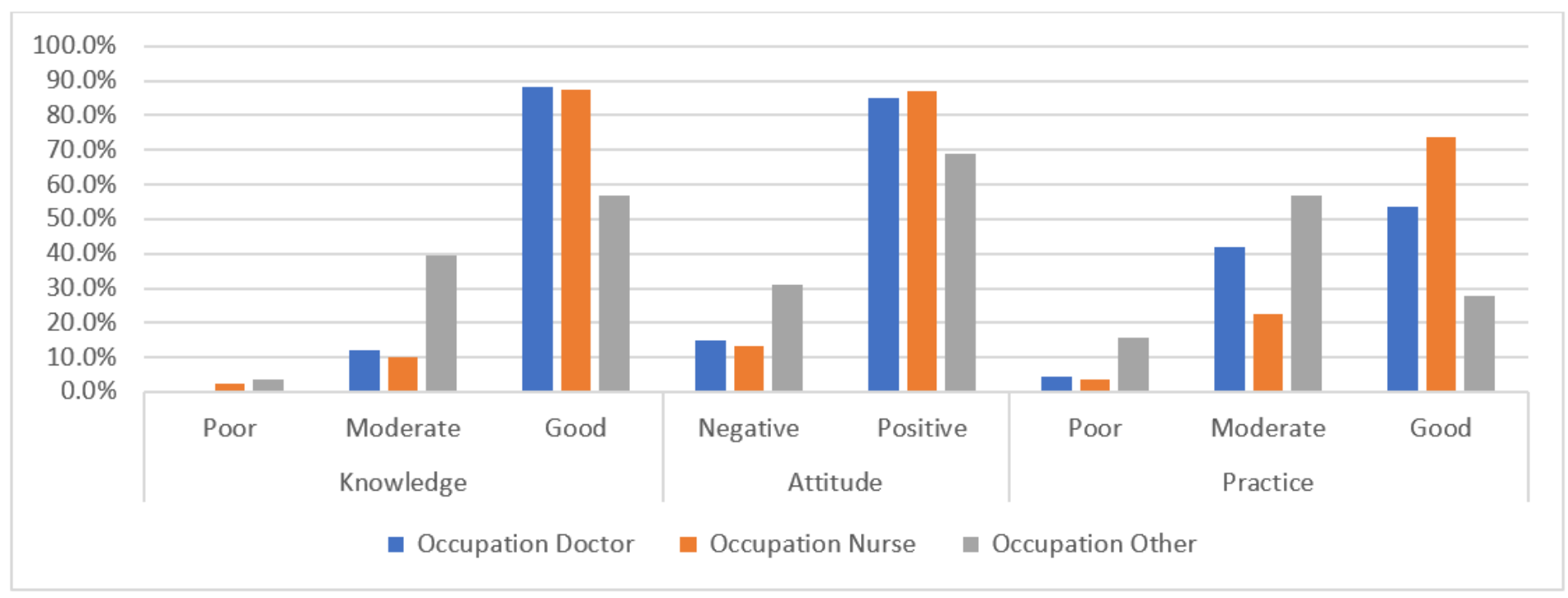

\section{Figure 4}

Distribution of knowledge, attitude and practice scores across professional group of healthcare workers Test relieved that there is a significant relation between the occupation and Knowledge, Attitude and practice, $p$-value $(<0.0005,0.007,<0.0005)$ respectively 